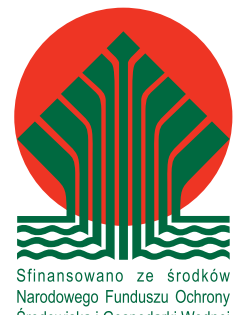

BIULETYN PAŃSTWOWEGO INSTYTUTU GEOLOGICZNEGO 461: 179-192, 2015 R.

\title{
PALEOMAGNETIC ANALYSES ON BADENIAN-SARMATIAN DRILL CORES FROM THE NORTH CARPATHIAN FOREDEEP (MIDDLE MIOCENE, POLAND)
}

\author{
ANALIZY PALEOMAGNETYCZNE RDZENI WIERTNICZYCH Z UTWORÓW BADENU-SARMATU \\ Z PÓŁNOCNEJ CZĘŚCI ZAPADLISKA PRZEDKARPACKIEGO (ŚRODKOWY MIOCEN, POLSKA)
}

\author{
Karin Sant ${ }^{1}$, Arjan de Leeuw ${ }^{1}$, Liao Chang ${ }^{1}$, Grzegorz Czapowski², Andrzej Gąsiewicz², Wout Krijgsman ${ }^{1}$
}

\begin{abstract}
Accurate dating of the Badenian-Sarmatian transition, a boundary between two regional Middle Miocene stages of the semi-isolated Paratethys Sea, is crucial to understand what event caused the corresponding major turnover in faunal assemblage at that point in time. The general opinion is that this event resulted from a sudden isolation of the Eastern Paratethys from ocean water, due to the closure of the Eastern Anatolian seaway to the Indian Ocean, but it remains debated if the final isolation had a tectonic or climatic cause. This pilot study presents paleomagnetic analyses of two drill cores from the North Carpathian Foredeep in Poland that straddle the Badenian-Sarmatian transition. Rock magnetic experiments, including thermomagnetic runs in air on a Curie balance, and hysteresis measurements on a MicroMag, indicate that the dominant magnetic carrier is the iron sulphide greigite. This is in agreement with the observed gyroremanence obtained during alternating field demagnetization above $40 \mathrm{mT}$. Alternating field and thermal demagnetization results are in good agreement and show a weak, mixed-polarity, signal for most of the Badenian, rapidly shifting to a much stronger and dominantly normal polarity signal in the Sarmatian part of the cores. First order reversal curves diagrams indicate that the greigite in the Sarmatian part is clearly of diagenetic origin, it thus most likely concerns a secondary overprint by the present-day field that cannot be used for magnetostratigraphic correlations. We conclude that the Paratethys-wide paleoenvironmental change that occurred at the Badenian-Sarmatian transition had probably also created different conditions for the formation and/or preservation of magnetic minerals.
\end{abstract}

Key words: Badenian-Sarmatian boundary, paleomagnetic dating, Northern Carpathian Foredeep.

Abstrakt. Dokładne datowanie przejścia baden-sarmat, granicy dwóch regionalnych pięter środkowego miocenu na terenie częściowo izolowanego morza Paratetydy, jest istotne dla zrozumienia przyczyny wyraźnej zmiany zespołów faunistycznych, która towarzyszyła temu wydarzeniu. Według powszechnie akceptowanych poglądów wydarzenie to było wynikiem nagłego odcięcia obszaru Paratetydy Wschodniej od otwartego oceanu wskutek zamknięcia cieśnin na terenie wschodniej Anatolii, które stanowiły łącznik z Oceanem Indyjskim. Obecnie przedmiotem dyskusji jest tektoniczna lub klimatyczna przyczyna tego wydarzenia. Paleomagnetyczne badania pilotowe rdzeni z dwóch otworów wiertniczych, położonych w północnej części zapadliska przedkarpackiego na terenie Polski, dotyczą przejściowej, badeńsko-sarmackiej sukcesji osadowej. Badania petromagnetyczne (w tym analizy termomagnetyczne na wadze Curie oraz histerezy na instrumencie MicroMag) wskazują, że dominującym minerałem magnetycznym jest siarczek żelaza - greigit, co potwierdza obecność składowej giromagnetycznej podczas rozmagnesowywania próbek zmiennym polem magnetycznym powyżej 40 mT. Wyniki polowej i termicznej demagnetyzacji są zgodne i wskazują na słaby sygnał, o mieszanej polarności, dla większości sukcesji badeńskiej, wzmocniony i zmieniający charakter na normalny dla części sarmackiej profilu. Odwrócone krzywe pierwszego rzędu dowodzą, że greigit w osadach sarmackich jest minerałem diagenetycznym, co bardziej wskazuje na wtórne nałożenie oddziaływania współczesnego pola magnetycznego i tym samym nie pozwala na przeprowadzenie korelacji magnetostratygraficznych. Autorzy stwierdzają, że zmiana paleośrodowiskowa w Paratetydzie na pograniczu badenu i sarmatu wpłynęła na powstanie i/lub dalsze przemiany minerałów o właściwościach magnetycznych.

Słowa kluczowe: granica baden-sarmat, datowania paleomagnetyczne, zapadlisko przedkarpackie.

\footnotetext{
${ }^{1}$ Paleomagnetic Laboratory 'Fort Hoofddijk', Faculty of Geosciences, Utrecht University, Budapestlaan 17, 3584 CD, Utrecht, The Netherlands; e-mail:W.Krijgsman@uu.nl.

${ }^{2}$ Państwowy Instytut Geologiczny - Państwowy Instytut Badawczy, Rakowiecka 4, 00-975 Warszawa; e-mail: grzegorz.czapowski@pig.gov.pl, andrzej.gasiewicz@pgi.gov.pl.
} 


\section{INTRODUCTION}

Plate-tectonic collision of the northward moving AfricaArabian continents with Eurasia led to the formation of the Alpine-Himalayan mountain chain during the Oligo-Miocene. These mountains subdivided the ancient Tethys Ocean into a northern Paratethys and a southern Mediterranean domain, separated by shallow sills from the Atlantic and Indian Ocean. Paratethys was an enormous epicontinental sea that stretched from Western Europe into central Asia at the beginning of the Oligocene, significantly influencing the paleoclimate and paleoenvironment of Eurasia (Ramstein et al., 1997). A complex combination of regional tectonic uplift and glacio-eustatic sea-level lowering caused progressive sea retreat to the present-day remnants: Black Sea and Caspian Sea. Paratethys environments gradually evolved from open marine settings into restricted marine and, ultimately, even into lacustrine settings. Associated with this transformation, marine fauna became increasingly replaced by highly endemic, fresh to brackish water biota (e.g., Harzhauser et al., 2002; Popov et al., 2006; Studencka, Jasionowski, 2011).

Gradual growth of the Alpine-Carpathian-Dinarides orogenic system during the Miocene induced progressive restriction of the Western, Central and Eastern Parate- thys. This geodynamically controlled paleogeographic and biogeographic differentiation caused major difficulties in stratigraphic correlation between the different parts of the Paratethys and the Mediterranean and led to the establishment of regional chronostratigraphic scales for the Paratethys (Fig. 1) (Piller et al., 2007). The Neogene time scale for the Central and Eastern Paratethys regions started to diverge during the middle to late Miocene by the uplift of the Carpathian orogen. Because of the overall absence of absolute age control, the regional time scale is largely based on correlations to the global sea level curves. In the Central Paratethys all stratotypes are located at shallow marginal settings and correspond to periods of relative sea level highstands and regional stage boundaries generally correspond with erosional gaps interpreted to reflect sea level lowstands (Piller et al., 2007). More accurate dating of the Paratethys substages is needed to provide a direct relationship with global climate history.

Recently, high-resolution magnetostratigraphic studies on long and continuous sedimentary successions in the Central and Eastern Paratethys comprising the SarmatianPannonian, Maeotian-Pontian and Pontian-Dacian bounda-

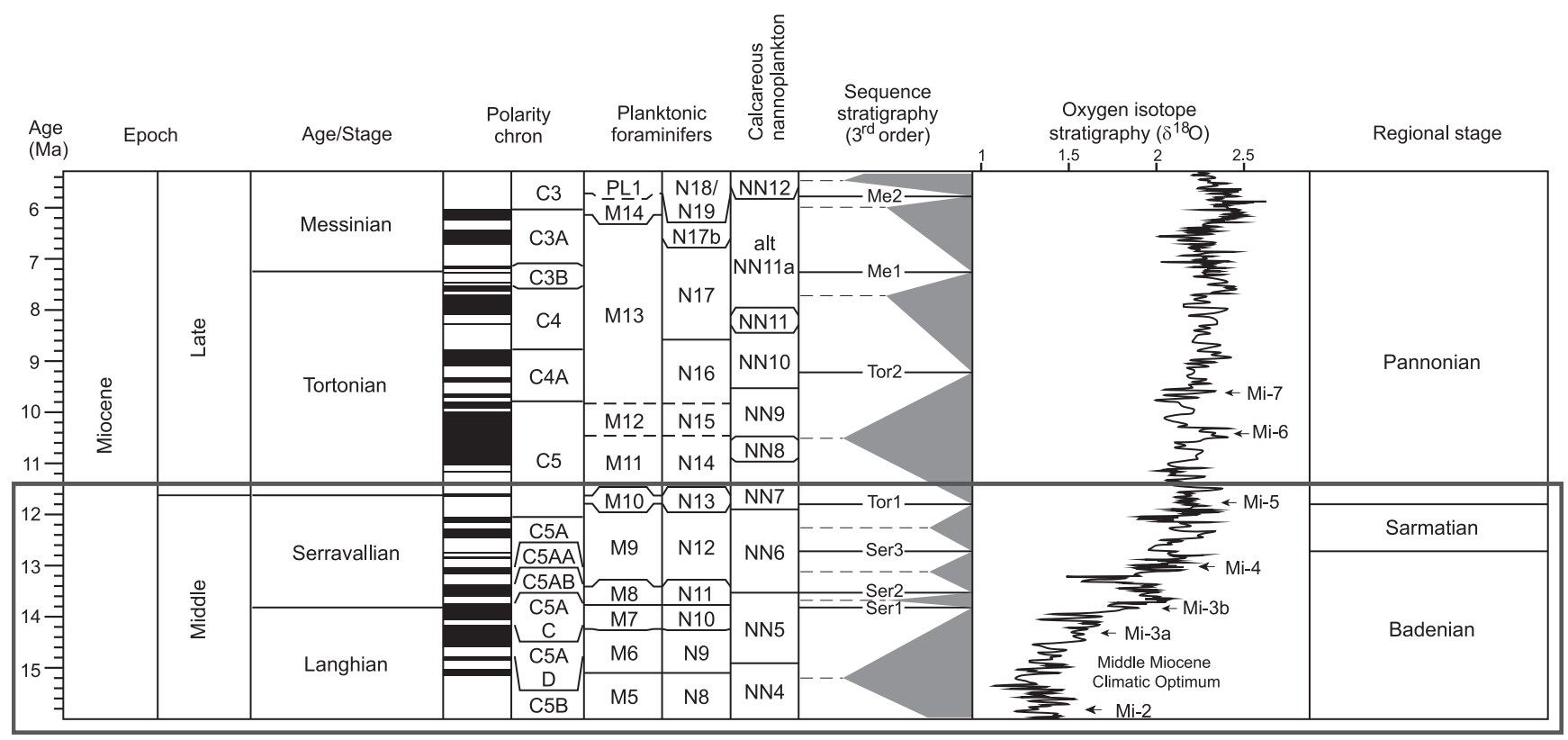

Fig. 1. Miocene chronology, geomagnetic polarity chrons, biozonations of planktonic foraminifers and calcareous nannoplankton, sequence stratigraphy and sea level curve, and oxygen isotope stratigraphy

The data has been partly recalibrated and correlated to regional chronostratigraphy of the Central Paratethys (after Piller et al., 2007). Grey inset denotes the study interval comprising the Badenian and Sarmatian stages

Zestawienie chronostratygrafii utworów miocenu z okresami normalnej i odwróconej polarności ziemskiego pola magnetycznego, biozonami wyznaczonymi przez otwornice planktoniczne i nanoplankton wapienny, wydzieleniami stratygrafii sekwencyjnej, krzywą wahań poziomu morza oraz ze stratygrafią opartą na zmianach zawartości izotopów tlenu 
ries resulted in correlations to the Geological Time Scale and a revised chronology for the Paratethys (Vasiliev et al., 2004, 2010; Krijgsman et al., 2010; Paulissen et al., 2011; de Leeuw et al., 2013). The magnetic signal of these sedimentary deposits was carried by two different populations of greigite $\left(\mathrm{Fe}_{3} \mathrm{~S}_{4}\right)$, a biogenic component of primary origin generated by magnetotactic bacteria, and an authigenic component of secondary origin that formed by diagenetic processes (Vasiliev et al., 2007, 2008). These new developments hold great promise that more stage boundaries will be more accurately dated in the nearby future. Here we will present new paleomagnetic analyses on two recently drilled cores comprising the Badenian-Sarmatian transition in the North Carpathian Foredeep of Poland (Czapowski, Gąsiewicz, 2015).

\section{BADENIAN-SARMATIAN TRANSITION - A GENERAL OVERVIEW}

Thin-skinned tectonic deformation in the Carpathian Foredeep directly affected the Miocene marine connections between the Central and Eastern Paratethys. At the start of the Badenian, the marginal basins of the Carpathian orogene subsided below the base level of the Paratethys and were flooded. A strong glacio-eustatic event in the Middle-Badenian caused a global sea level drop, restricted the connection with the Mediterranean and up to $300 \mathrm{~m}$ thick salt deposits accumulated in the deepest parts of the Central Paratethys (e.g., de Leeuw et al., 2010). In the Late-Badenian (Kosovian), intensified nappe-stacking of the Eastern Carpathians increased the subsidence of its foredeep (Matenco, Bertotti, 2000; Vasiliev et al., 2009). The Eastern Anatolian seaway reopened, so that the Paratethys reconnected to the Indian
Ocean (Fig. 2) (Rögl, 1999) and a transgression overflowed the whole region.

The Badenian-Sarmatian transition corresponds to a major turnover in faunal elements, triggered by strong restriction to the open ocean connections. Of the Badenian fauna, 588 last occurrences of gastropods and 121 of foraminifers are recorded and this event is designated as the strongest turnover event of the Paratethys history, also termed the Badenian-Sarmatian Extinction Event (BSEE) (Harzhauser, Piller, 2007). The faunal re-orientation was triggered by a strong restriction of the open-ocean connections of the Central and Eastern Paratethys. The base of the Sarmatian was defined by the occurrence of a highly endemic fauna, particularly molluscs and to a lesser extent foraminifers.

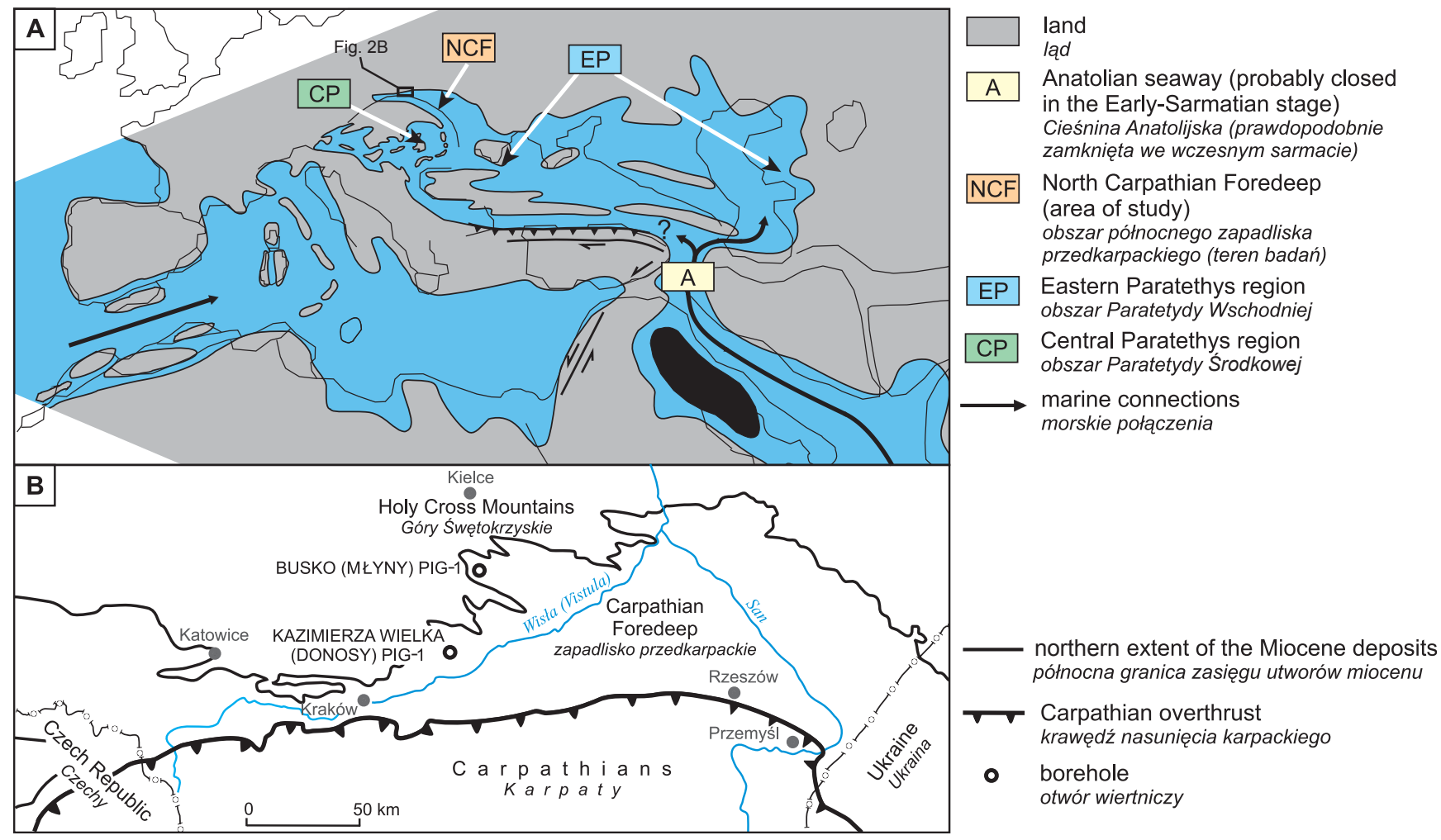

Fig. 2. A. Schematic palaeogeography of the Paratethys region in the Late Badenian (after Rögl, 1999).

B. Location of studied boreholes (after Paruch-Kulczycka, 2015)

A. Schematyczny szkic paleogeograficzny obszaru Paratetydy w późnym badenie (wg Rögl, 1999).

B. Lokalizacja badanych otworów wiertniczych (wg Paruch-Kulczyckiej, 2015) 
Both groups allow the establishment of an ecostratigraphic subdivision. A commonly used biostratigraphic subdivision for the Badenian-Sarmatian transition is the change in benthic foraminifera biozones from assemblages corresponding to the Tenuitellinata sp. zone (Filipescu, Silye, 2008) to assemblages belonging to the Anomalinoides (or Lobatula) dividens zone (Łuczkowska, 1967; Oszczypko, Ślączka, 1989).

Contemporaneous with the abrupt increase in endemics, a total loss in stenohaline biota occurs at the BadenianSarmatian boundary. Since radiolarians, planktonic foraminifera, corals and echinoderms are often absent, the Sarmatian was also termed the "brackish stage", although others presented normal marine conditions for most of the Sarmatian.

At the Badenian-Sarmatian transition, many fossil studies report an abrupt salinity decrease from $30 \%$ to $17-22 \%$ and an alkalinity increase (Pisera, 1996), but the decrease has not been recorded everywhere in the Paratethys. Some studies even suggest hypersaline periods (Crihan, 2002). The general opinion is that the connection to the Indian Ocean through the Eastern Anatolian seaway closed again (Rögl, 1999 and references therein) and disconnected the Eastern Paratethys from the open ocean. The Sarmatian sea became a shallow, isolated basin, probably subject to both seasonal and long-term climatic variations, which induced extreme variations of salinity and temperature (Crihan, 2002). In the Sarmatian, the final collision phase of the Tisza microplate with the Eastern European Craton took place and subduction of the basins stopped. The uplift led to the ultimate isolation of the Central Paratethys at the Sarmatian-Pannonian boundary at an age of 11.6 Ma (Ter Borgh et al., 2013).

Exact dating of the Badenian-Sarmatian transition could give an insight in what event exactly caused the shift in faunal assemblage. One problem with this boundary is the occurrence of an unconformity in many areas, where either the top of the Badenian or the lower part of the Sarmatian is missing, or both (Crihan, Marunteanu, 2006). The most recent proposed correlation of the Badenian-Sarmatian transition is to the Ser3 sequence boundary (Fig. 1), a sea level lowstand related to the glacio-eustatic isotope event MSi-3 at an age of 12.7 Ma (Piller et al., 2007). This age is supported by a combination of magnetostratigraphy and radio-isotopic (Ar/Ar) dating on the sedimentary successions of the Transylvania Basin in Romania (de Leeuw et al., 2013).

Here, we aim to establish a magnetostratigraphic correlation for the Badenian-Sarmatian transition in two recently drilled cores from the North Carpathian Foredeep in southern Poland. This region has been relatively deep throughout the Badenian and the Badenian-Sarmatian transition most probably took place under continuous deposition in deep water setting, without visible breaks/hiatuses or condensation in the sedimentary record (Ney et al., 1974; Krzywiec, 2001; Gąsiewicz et al., 2004; Czapowski, Gąsiewicz, 2015).

\section{DRILL CORES FROM THE NORTH CARPATHIAN FOREDEEP OF POLAND - GEOLOGICAL BACKGROUND}

The Miocene series of the northern part of the Carpathian Foredeep consists of thick, mainly clastics sediments locally exceeding $3.5 \mathrm{~km}$. The series comprise a relatively thin (up to about $60 \mathrm{~m}$ thick) evaporite unit (e.g., Ney et al., 1974; Pawłowski et al., 1979, 1985; Gąsiewicz, 2000; Oszczypko, Oszczypko-Clowes, 2012 with references) in their lower part. Both clastic (sands, sandstones, sandy limestones) and carbonate lithofacies (coralline algal limestones), characterized by variable thickness (up to about $150 \mathrm{~m}$ ), underlie the evaporites. These clastic-carbonate deposits, called the Baranów Beds or Pińczów Fm. (nearshore equivalent of Skawina Fm.) and belonging to the Lower Badenian, are the basal Miocene deposits in the northern Foredeep. The overburden of the chemical unit (gypsum and related sulphur-bearing limestones called Krzyżanowice Fm. and rock salts called Wieliczka Fm.) in this area of the Carpathian Foredeep consists of a marine, monotonous, mainly pelitic, and relatively very thick clastic (marls and siltstones) complex (called Machów Fm.) of Late-Badenian to Sarmatian age (e.g., Pawłowski et al., 1979; 1985; Gąsiewicz et al., 2004). The thickness of the Machów Fm. varies from several tens of meters to over $3.4 \mathrm{~km}$ in the south-eastern part of Carpathian Foredeep (Ney et al., 1974). In the Foredeep margin the marine nearshore coarse clastic unit (sands to gravels and conglomerates) of the Sarmatian age was devel- oped, called the Chmielnik Fm., which is up to $40 \mathrm{~m}$ thick (e.g., Czapowski, 1984; Czapowski, Studencka, 1990; Jasionowski 1997). These marine nearshore to deltaic deposits are a time equivalent of the dominantly pelitic open marine facies of the Machów Fm.

Lithologically, the Badenian-Sarmatian transition between these stratigraphic units is continuous. The complex contains highly endemic fossil assemblages. Consequently, a biostratigraphic division of the complex to separate the Badenian and Sarmatian units based on macro- and microfauna as well as microflora appears as highly ambiguous. Although the complex is lithologically monotonous, it exhibits changes in geochemical patterns allowing its subdivision into lower and upper series. The boundary between them may be linked to the Badenian-Sarmatian transition (Gąsiewicz et al., 2004). However, bio- and chemostratigraphic methods are neither suitable to settle the boundary firmly nor to allow for wider interregional correlations.

Former paleomagnetic studies of the Machów Fm. deposits (in the single Jamnica S-119 core) in the late 90-ties of the twentieth century enabled to propose for the first time their paleomagnetic subdivision correlated with the current Global Polarity Time Scale. Moreover, the greigite occurrence was then detected (Król, Jeleńska, 1999). Also the whole deposition time of the studied Machów Fm. profile 
was calculated to be $3.4 \mathrm{Ma}$ and the controversial absolute age result of $11 \mathrm{Ma}$ for tuffites from the lower part of section was presented (Banaś, 1996 in: Król, Jeleńska, 1999). Other studies of the same core documented the environmental and sedimentary changes during deposition of the Machów Fm. Palynofacies analysis (Gedl, 1999) showed the environmental and climatic significance of Sarmatian palynoflora assemblages (Sadowska, 1999). Also, the first findings of microfaunal representatives (Silicoplacentina) of the Tecamoebians group were reported, hitherto known as characteristic for the Lower Pannonian (Paruch-Kulczycka, 1999).

Two new boreholes were drilled in the Polish part of the Carpathian Foredeep in 2010. The boreholes are located in the northern part of the Carpathian Foredeep (Czapowski, Gassiewicz, 2015) continuing to the southern slope of the Holy Cross Mts massif, where the sedimentation has developed as mostly pelitic (clays, marls with rare fine sands/ sandstone interbeds and local tuffite intercalations) open marine deposits with anaccessible thickness of 150-200 m. The Busko (Młyny) PIG-12 borehole comprises the succession of the Machów Fm. (122.5 m) and the Chmielnik Fm. (33.7 m), which is underlain by the sulphate deposits of Krzyżanowice Fm. (over $30 \mathrm{~m}$ ). The Kazimierza Wielka (Donosy) PIG-1 borehole is located ca. $40 \mathrm{~km}$ southward toward the foredeep center. Its profile consists of the Machów Fm. (161.4 m thick) underlain there by the Badenian evaporite unit (Krzyżanowice Fm., only $3 \mathrm{~m}$ of its top was drilled) and overlain directly by Quaternary accumulates with a thickness of $27.3 \mathrm{~m}$ (Czapowski, Gąsiewicz, 2015). The samples from Kazimierza Wielka (Donosy) PIG-1 and Busko (Młyny) PIG-1 boreholes comprise the Machów Fm. deposits and contain the Badenian-Sarmatian transition interval in the Carpathian Foredeep.

\section{METHODS}

Two cores of the Kazimierza Wielka (Donosy) PIG-1 and Busko (Młyny) PIG-1 boreholes were sampled in Poland for paleomagnetic analyses in the Paleomagnetic laboratory Fort Hoofddijk of Utrecht University, The Netherlands. Paleomagnetic samples from the Busko (Młyny) PIG-1 core were collected with a hand-held gasoline-powered drill using water as a coolant. The Kazimierza Wielka (Donosy) PIG-1 was much more difficult to sample because of the laminated nature of the rock and only oriented hand samples were taken. These hand samples were later drilled in the Utrecht lab with compressed air.

\section{ROCK MAGNETIC EXPERIMENTS}

A range of rock magnetic experiments were performed to identify the magnetic carriers and the presence of magnetic interactions for samples from different stratigraphic levels. The room-temperature magnetic susceptibility of the samples was measured on a Kappabridge KLY-2. In order to correct the susceptibility for the sample's mass, the measured susceptibility values were divided by sample weight yielding the specific magnetic susceptibility. Thermomagnetic measurements were performed in air up to $700^{\circ} \mathrm{C}$ with a modified horizontal translation type Curie balance (noise level $5 \times 10^{-9} \mathrm{Am}^{2}$ ). Hysteresis loops, isothermal remanent magnetization (IRM) acquisition and back field demagnetization curves, and first-order reversal curve (FORC) diagrams were measured with a Princeton MicroMag alternating gradient magnetometer (AGM). Hysteresis parameters, including the saturation magnetization $\left(M_{s}\right)$, the saturation remanent magnetization $\left(M_{r s}\right)$, the coercive force $\left(B_{c}\right)$ and the coercive remanence force $\left(B_{c r}\right)$, were determined from hysteresis loops and back field demagnetization curves. The sample was measured with 200 FORCs. A smoothing factor of 3 is used to calculate the FORC distribution.

\section{ALTERNATING FIELD AND THERMAL DEMAGNETIZATION}

The obtained cores were cut into several specimens that were subsequently stepwise demagnetized in the paleomagnetic laboratory. Demagnetization was accomplished by a laboratory-built automated measuring device applying 16 5-20 mT increments up to $100 \mathrm{mT}$ by means of an AF-coil interfaced with the magnetometer. The natural remanent magnetization (NRM) of the samples was measured after each demagnetization step on a $2 \mathrm{G}$ Enterprises DC SQUID cryogenic magnetometer (noise level $3 \times 10^{-12} \mathrm{Am}^{2}$ ). Since we expected that the sediment may contain greigite, we have taken extra steps in small increments between $25 \mathrm{mT}$ and $40 \mathrm{mT}$, because for greigite we often find the generation of a Gyroremanent Magnetization (GRM) at fields higher than $40 \mathrm{mT}$. In order to overcome the problem of gyroremanence

${ }^{2}$ The names of boreholes are given according to the documentation. 
during alternating field demagnetization the specifically designed per component demagnetization scheme of Dankers and Zijderveld (1981) was applied. This method involves longer measuring and processing on the robotized system, but tries to eliminate as much as possible the growing GRM component at higher alternating fields. We have processed in total 136 samples - 88 samples from the Busko (Młyny) PIG-1 core (BS) and 48 samples from the Kazimierza Wielka (Donosy) PIG-1 core (KZ).

A selected series of samples from the Kazimierza Wielka (Donosy) PIG-1 core were also thermally demagnetized with successive heating steps of: $20-100-180-200-220-240^{\circ} \mathrm{C}$. After each heating step, the magnetic susceptibility for ten reference samples was measured and compared to the values at room temperature. When the magnetic susceptibility changed the samples were not heated any further to prevent a conversion from iron sulfide to iron oxide. For weak samples, the oxidation started already at $\mathrm{T}=220^{\circ} \mathrm{C}$ while for the strongest samples it was not observed at all. After thermal treatment, the samples were further demagnetized using the AF method described above.

The characteristic remanent magnetization (ChRM) was identified through assessment of decay-curves and vector end-point diagrams (Zijderveld, 1967). ChRM directions were calculated by principal component analysis (Kirschvink, 1980). Since the cores were not oriented, only the inclination can be used to establish the magnetostratigraphy.

\section{RESULTS}

\section{ROCK MAGNETISM}

Room-temperature magnetic susceptibility of the KZ samples is highly variable and ranges from 9.2E-9 to $3.3 \mathrm{E}-7 \mathrm{~m}^{3} / \mathrm{kg}$ (Fig. 3). The thermomagnetic curve of a selected sample (Fig. 4A) is characterized by a dominating hyperbolic decrease in magnetization below $400^{\circ} \mathrm{C}$, which reflects the dominance of paramagnetic minerals. The warming and cooling sub-cycles indicate that the magnetization is irreversible between $200^{\circ} \mathrm{C}$ and $400^{\circ} \mathrm{C}$ (Fig. $4 \mathrm{~A}$ ). For example, there is a detectable decrease in magnetization after cooling and heating back with a significant drop in magnetization between $250^{\circ} \mathrm{C}$ and $350^{\circ} \mathrm{C}$ (Fig. 4A). This thermomagnetic behaviour is consistent with thermal breakdown of greigite during heating (Roberts, 1995; Roberts et al., 2011). Above $400^{\circ} \mathrm{C}$, the magnetization increases gradually with a peak near $500^{\circ} \mathrm{C}$. This increase is probably associated with the formation of magnetic mineral due to pyrite oxidation during heating (e.g., Butler, 1992; Passier et al., 2001; Roberts et al., 2011). This magnetization is removed near $580^{\circ} \mathrm{C}$, which indicates that it has converted into magnetite $\left(T_{c}=580^{\circ} \mathrm{C}\right)$. Between $580^{\circ} \mathrm{C}$ and $700^{\circ} \mathrm{C}$, the heating and cooling curves do not undergo further changes and are almost reversible.

Hysteresis properties of several $\mathrm{KZ}$ samples were measured to better characterize the magnetic mineralogy and magnetic properties. Randomly selected samples (KZ85, KZ97 and KZ112) from the long normal polarity interval $(-150 \mathrm{~m}$ to $-30 \mathrm{~m}$ ) all show strong magnetization. These samples also have large $B_{c}$ (39-44 $\left.\mathrm{mT}\right)$ and $M_{r s} / M_{s}$ values $(0.40-0.47)$. These values are in the range of hysteresis parameters for single domain (SD) sedimentary greigite (e.g., Roberts, 1995; Vasiliev et al., 2007; Roberts et al., 2011). FORC diagrams indicate strong SD behaviour with strong magnetostatic interactions (Fig. 4B), which are characteristics of diagenetic sedimentary greigite (e.g., Roberts et al., 2006; Vasiliev et al. 2007). Samples below the long normal polarity interval are magnetically weak. Hysteresis loops indicate dominance of paramagnetic minerals. After paramagnetic correction, these samples show pseudo-single-domain (PSD) property with low $B_{c}(14-17 \mathrm{mT})$ and $M_{r s} / M_{s}(0.14-0.19)$ values. The distinct magnetic property between strong SD greigite from the long normal polarity interval and weak PSD below coincides with the polarity transition. This probably indicates neoformation of significant amount of diagenetic greigite within the long normal polarity interval. This questions the reliability of the magnetostratigraphy as they probably indicate secondary overprint components.

\section{MAGNETOSTRATIGRAPHIC}

Many samples showed evidence of a GRM acquisition during AF demagnetization (Fig. 5), which often reached magnetizations higher than the NRM, sometimes to more than one order of magnitude. This is typical for SD sedimentary greigite (e.g., Snowball, 1997; Roberts et al., 2011). Combining with rock magnetic measurements, we can thus firmly conclude that greigite is the dominant magnetic carrier in the rocks of the Machów Fm.

The results from the Busko (Młyny) PIG-1 core show very weak and often scattered directions. Diagrams are relatively unclear due to the low remanence. The results for the Kazimierza Wielka (Donosy) PIG-1 core are much better, albeit commonly with a large GRM (Fig. 5). A high intensity signal and clear magnetic directions characterize the majority of the section. The majority of the samples could be interpreted and the straight line through several consecutive data points, mostly also including the origin, denotes the vector that represents the interpreted paleomagnetic direction. During alternating field demagnetization, iron sulfides build up a gyro-remanence, which leads to a high increase in intensity and disturbs the demagnetization diagrams above $45 \mathrm{mT}$. The provided directions are therefore generally based on vector endpoints for fields between $20 \mathrm{mT}$ and $40 \mathrm{mT}$. 
In the thermal demagnetization diagrams, a viscous component is removed between $20-100^{\circ} \mathrm{C}$. A second component, decays towards the origin up to $220^{\circ} \mathrm{C}$ and $40 \mathrm{mT}$ (Fig. 6). This component shows both normal and reversed polarities. At a certain point, almost all samples develop a random orientation. Some weak samples develop a random direction already at $\mathrm{T}<220^{\circ} \mathrm{C}$. The paleomagnetic results have been divided in a good, intermediate and low quality group (Tab. 1).

Since the orientation of the samples with respect to north is unknown, only the inclination values can be analyzed. Plotting the ChRM directions of the second component for the Kazimierza Wielka (Donosy) PIG-1 borehole in stratigraphical order (Fig. 7) results in a preliminary magnetostratigraphy. The differences between the alternating field and thermal demagnetization results are minor. The alternating field record indicates more normal polarities in the lower part, while the thermal record has more uncertainties. The lower part of the core shows a relatively weak signal and a somewhat unreliable polarity pattern $(-190 \mathrm{~m}$ to $-150 \mathrm{~m})$. Although a high quantity of samples was taken in the lowest interval $(-190 \mathrm{~m}$ to $-180 \mathrm{~m})$ the quality of the data is low. The base of the core seems to be of reversed polarity, although characterized by only one high-quality level $(-190 \mathrm{~m})$. A normal polarity interval may be present between $-185 \mathrm{~m}$ and $-170 \mathrm{~m}$, and the interval between $-170 \mathrm{~m}$ and $-150 \mathrm{~m}$ suggests reversed polarities, but the signal in these intervals is admittedly weak. The upper part $(-150 \mathrm{~m}$ to $-30 \mathrm{~m})$ has much higher intensities and shows a dominantly normal polarity interval. A thick sandstone bed is present between $-135 \mathrm{~m}$ and $-120 \mathrm{~m}$, complicating a more detailed sampling in this interval.

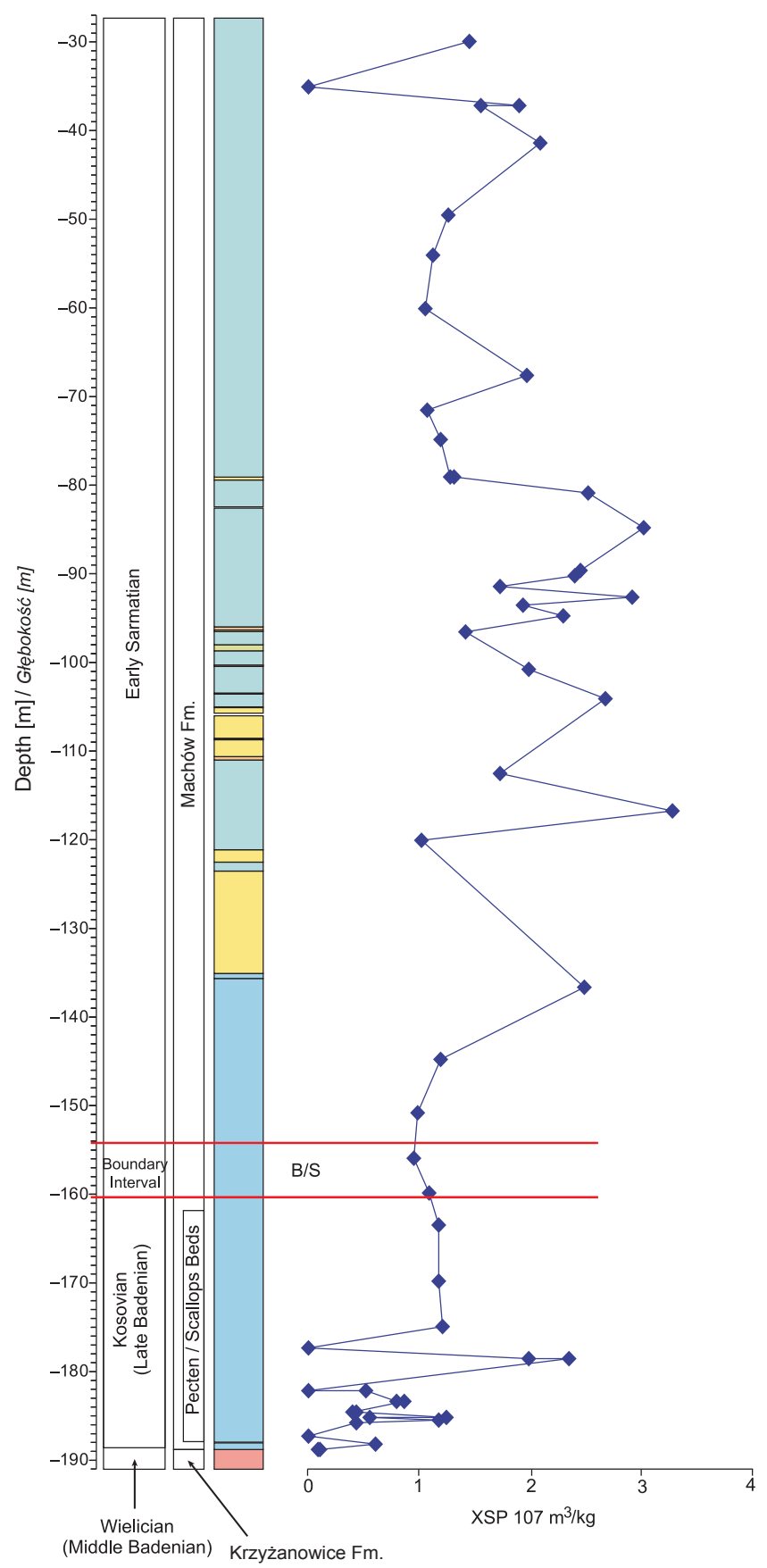

Fig. 3. Simplified log of Kazimierza Wielka (Donosy) PIG-1 core and magnetic susceptibility profile

Zone of the Badenian-Sarmatian boundary, based on biostratigraphic data, is marked with red lines and $\mathrm{B} / \mathrm{S}$

Uproszczony profil geologiczny otworu wiertniczego

Kazimierza Wielka (Donosy) PIG-1 z wykresem zmierzonej podatności magnetycznej pobranych próbek skalnych

Czerwoną linią i literami B/S zaznaczono pozycję biostratygraficznej granicy baden-sarmat

sand, silty sand, clayey sand

piasek, piasek mulasty, piasek zailony

gravel, sandy grave

żwir, żwir piaszczysty

rhythmite of sand and clay

rytmit piasku i iłu/ mułku

clayey silt, rhythmite of clay and silt

mułek ilasty, rytmit iłu i mułku

\section{clay}

gypsum, gypsum breccia, clayey gypsum gips, brekcja gipsowa, gips zailony 

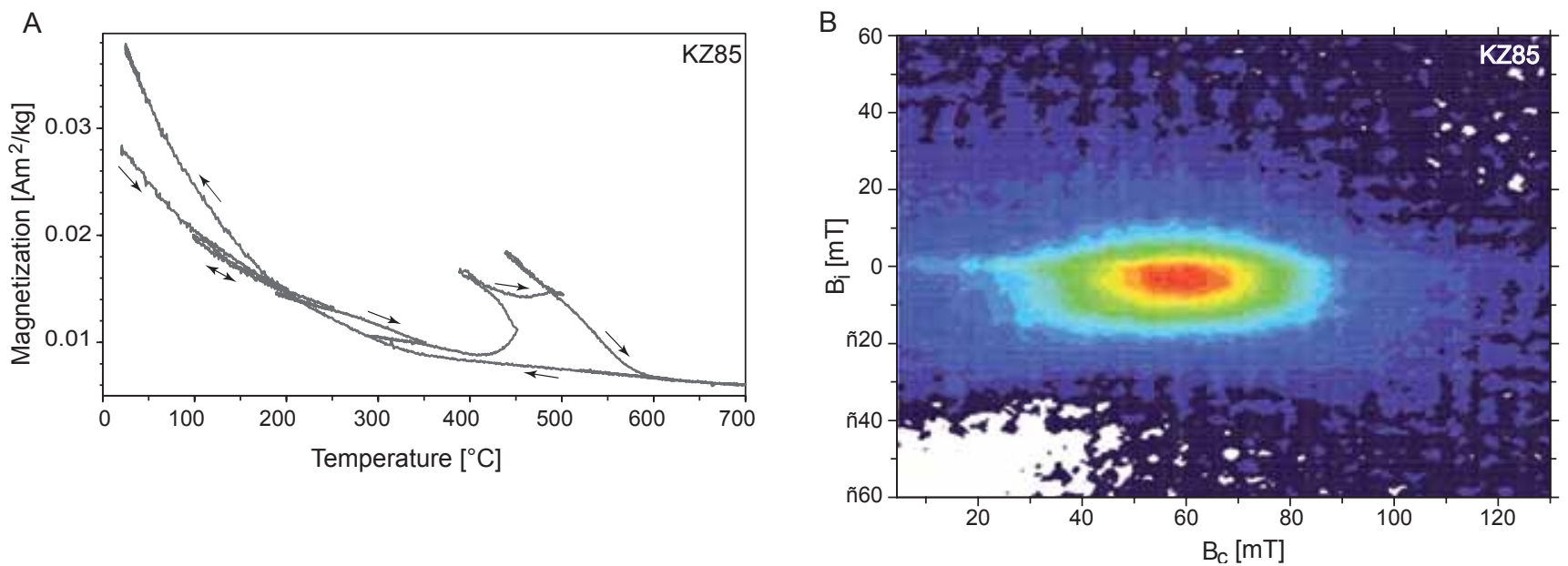

Fig. 4. Representative rock magnetic results for samples from the Kazimierza Wielka (Donosy) PIG-1 core

A. Thermomagnetic runs during multiple heating and cooling with a rate of $10^{\circ} \mathrm{C}$ per miniute. Arrows indicate heating or cooling. B. First-order reversal curve (FORC) diagram. $\mathrm{B}_{i}[\mathrm{mT}]$ provides a measure of the interactive field and $\mathrm{B}_{c}[\mathrm{mT}]$ measures the coercivity. The concentric countours with a large vertical spread, as well as the slight shift of countours to the negative value, indicate a strongly interacting single domain (SD) assemblage, which are common for diagenetic sedimentary greigite

Wybrane, reprezentatywne wyniki badań właściwości magnetycznych próbek z otworu wiertniczego Kazimierza Wielka (Donosy) PIG-1

A. Wynik analizy termomagnetycznej próbki KZ85 poddanej wielokrotnemu, stopniowemu podgrzewaniu i ochładzaniu z prędkością $10^{\circ} \mathrm{C} / \mathrm{min}$. Strzałki wskazują na kolejne fazy podgrzewania i ochładzania. B. Wykres odwróconej krzywej pierwszego rzędu (FORC). Oś Bi [mT] odpowiada pomiarom w zmiennym polu magnetycznym, natomiast oś $\mathrm{Bc}[\mathrm{mT}]$ - pomiarom koercywności. Zarówno koncentyczne kontury z dużym pionowym rozciagnięciem, jak i lekkie ich przesunięcie w strone wartości ujemnych Bi wskazują na obecność silnie ze sobą oddziałującego zespołu ziaren jednodomenowych (SD), co jest pospolite w przypadku diagenetycznego, osadowego greigitu

Table 1

Division of the paleomagnetic directions in samples from the Kazimierza Wielka (Donosy) PIG-1 borehole into three quality groups (these are plotted with different symbols in Figure 7)

Podział wyznaczonych kierunków paleomagnetycznych w próbkach z otworu wiertniczego

Kazimierza Wielka (Donosy) PIG-1 na trzy grupy jakościowe (oznaczone symbolami na figurze 7)

\begin{tabular}{|c|c|c|c|c|c|c|c|}
\hline \multirow{2}{*}{ Group } & \multirow{2}{*}{$\begin{array}{c}\text { Symbol } \\
\text { (Fig. 7) }\end{array}$} & \multirow{2}{*}{ Quality } & \multicolumn{2}{|c|}{ Vector stable during demagnetization steps } & \multicolumn{3}{|c|}{ Number of samples } \\
\cline { 3 - 7 } & & TH + AF & AF & N & R & U \\
\hline KZ1 & closed circle & $1-2$ & $220^{\circ} \mathrm{C}-30 / 40 \mathrm{mT}$ & $20-40 \mathrm{mT}$ & 61 & 9 & - \\
\hline KZ2 & open circle & $2-3$ & $220^{\circ} \mathrm{C}-20 \mathrm{mT}$ & $20-30 \mathrm{mT}$ & 9 & 5 & - \\
\hline \multirow{2}{*}{ KZ3 } & cross & $\mathbf{S}$ & $>220^{\circ} \mathrm{C}$ & - & - & - & 9 \\
\cline { 3 - 8 } & & $\mathbf{Z}$ & $<220^{\circ} \mathrm{C}$ & - & - & 5 \\
\hline
\end{tabular}

The more linear the plotted magnetic vector, the lower is the quality number, thus KZ1 has the highest quality. Directions of group KZ1 are stable up to a high field, while the directions of intermediate group $\mathbf{K Z 2}$ are generally stable up to a slightly lower field range. Samples that yielded results of too low a quality to define a reliable direction $(\mathbf{Z})$, or yielded directions with a very shallow inclination $\left(-10^{\circ}<\mathrm{I}<10^{\circ}\right)[\mathbf{S}]$ were attributed to group KZ3. Results from this group cannot be used for interpretation of the polarity pattern. Per group, the number of reversed (R), normal (N) and unreliable (U) samples have been indicated below. $\mathbf{T H}+\mathbf{A F}$ - samples that were first thermally demagnetized up to $240^{\circ} \mathrm{C}$ and then further demagnetized with alternating field; $\mathbf{A F}-$ alternating field demagnetized samples

Im bardziej linearny jest charakter wykresu zapisu sygnału magnetycznego tym niższa jego jakość. Grupę KZ1 cechuje najwyższa jakość i stabilność w polu o wysokiej wartości, natomiast grupę KZ2, o średniej jakości danych - stabilność w polu nieco niższej wartości. Do grupy KZ3 zaliczono próbki o zbyt niskiej jakości by określić wiarygodne kierunki paleomagnetyczne $(\mathbf{Z})$ oraz próbki wykazujące bardzo małą inklinację $\left(-10^{\circ}<\mathrm{I}<10^{\circ}\right)[\mathrm{S}]$. Wyniki tej ostatniej grupy nie mogą być wykorzystane do interpretacji zmian polarności.W ramach grup przedstawiono liczbę próbek o odwróconej (R) i normalnej (N) polarności i próbek nieprzydatnych do interpretacji $(\mathbf{U})$. $\mathbf{T H}+\mathbf{F}$ - próbki wstępnie termicznie rozmagnesowane w temperaturze do $240^{\circ} \mathrm{C}$, a następnie rozmagnesowane w zmiennym polu magnetycznym; $\mathbf{A F}$ - próbki rozmagnesowane w zmiennym polu magnetycznym 

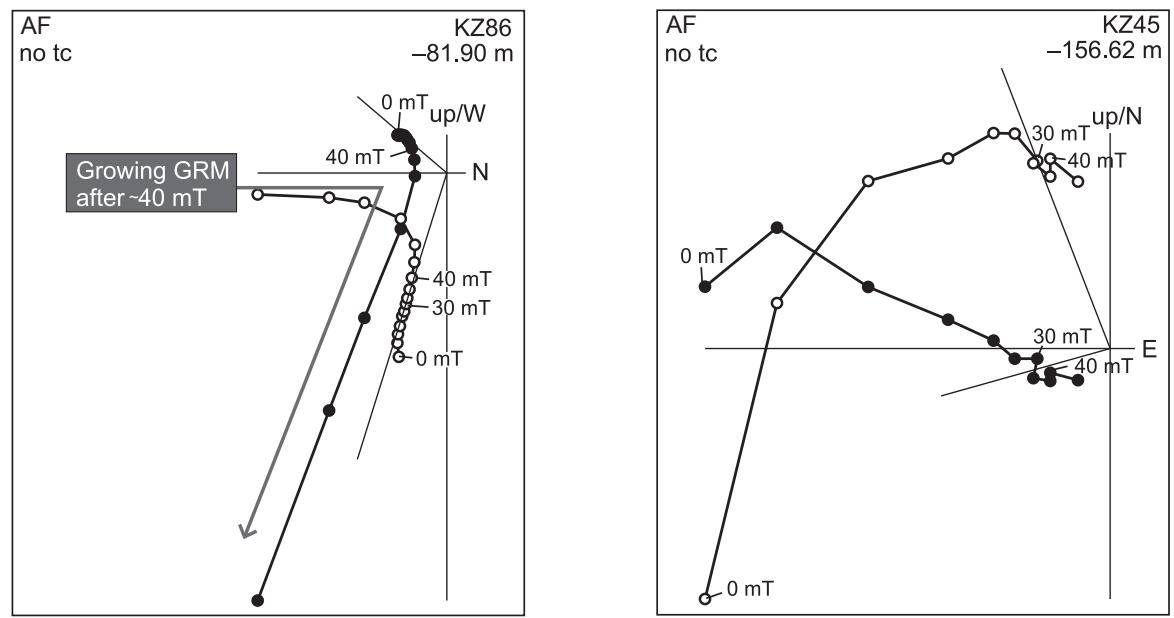

$\begin{array}{cl}\text { KZ45 } & \begin{array}{l}\text { indication of sample } \\ \text { oznaczenie próbki }\end{array} \\ -81.90 \mathrm{~m} & \begin{array}{l}\text { stratigraphic height } \\ \text { głębokość pobrania próbki }\end{array} \\ \text { no tc } & \begin{array}{l}\text { no tectonic correction } \\ \text { brak poprawki tektonicznej }\end{array} \\ \mathrm{W}, \mathrm{N}, \mathrm{E} \quad & \begin{array}{l}\text { West, North, East } \\ \text { zachód, północ, wschód }\end{array} \\ 30 \mathrm{mT} \quad \begin{array}{l}\text { field steps } \\ \text { natężenia pól magnetycznych } \\ \text { declination } \\ \text { deklinacja } \\ \text { inclination } \\ \text { inklinacja }\end{array} \\ \end{array}$

Fig. 5. Typical, high quality alternating field (AF) demagnetization diagrams of samples from the Kazimierza Wielka (Donosy) PIG-1 core

Sample KZ86 shows a strong increase in magnetization after $40 \mathrm{mT}$ related to the acquisition of gyroremanence (GRM). This indicates that the magnetic signal is carried by the iron sulfide greigite. The inclination in the $20-40 \mathrm{mT}$ interval is downward directed indicating a normal polarity. Sample KZ45 shows no major increase after $40 \mathrm{mT}$ and has inclinations that are upward directed indicating a reversed polarity

Typowe wykresy rozmagnesowania zmiennym polem magnetycznym (AF) próbek z otworu wiertniczego Kazimierza Wielka (Donosy) PIG-1

Próbka KZ86 wykazuje silny wzrost namagnesowania w polach rozmagnesowujących o natężeniu powyżej $40 \mathrm{mT}$, wywołany przez nabywanie gyroremanencji (GRM). Wskazuje to, że nośnikiem sygnału magnetycznego jest siarczek żelaza - greigit. Inklinacja magnetyczna dla próbki w interwale 20-40 mT wskazuje na normalną polarność ziemskiego pola magnetycznego. Próbka KZ45 nie wykazuje większego wzrostu namagnesowania w trakcie procesu jej rozmagnesowywania zmiennym polem magnetycznym (powyżej $40 \mathrm{mT}$ ) i ma ujemną inklinację magnetyczną, wskazująca, że jej pozostałość magnetyczna powstała w okresie odwróconej polarności ziemskiego pola magnetycznego
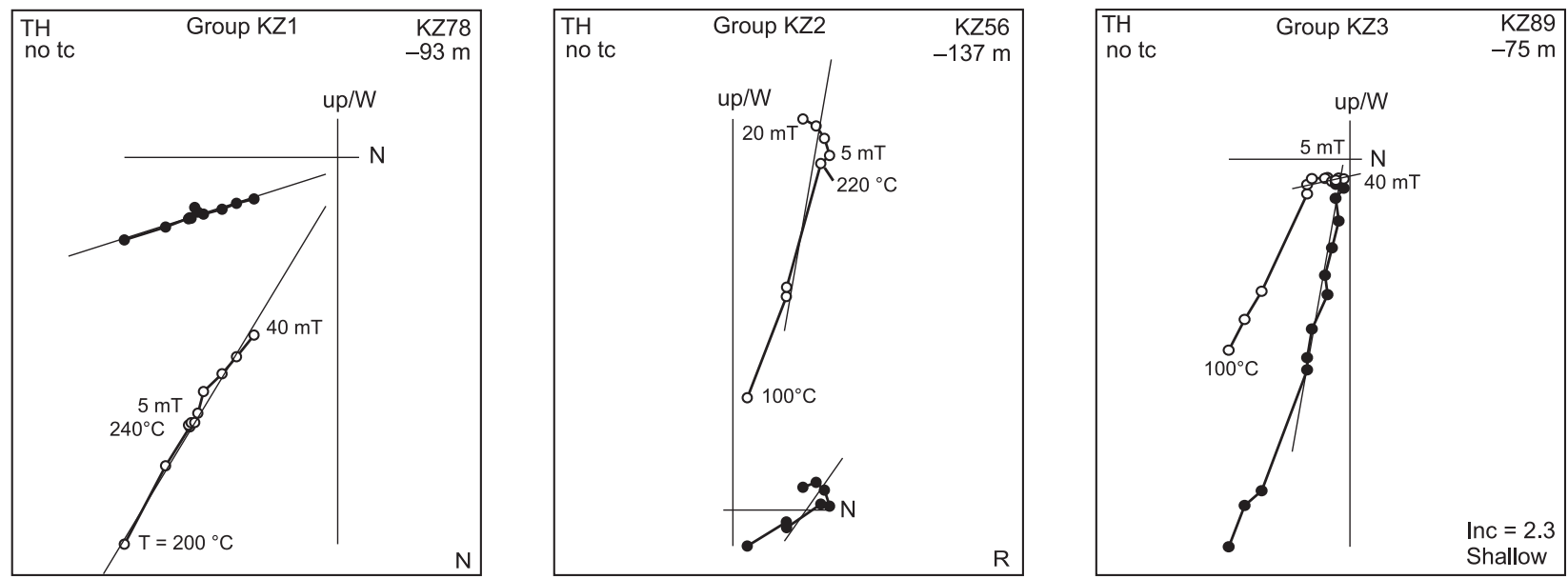

Fig. 6. Representative examples of thermal (TH) demagnetization diagrams of samples of Kazimierza Wielka (Donosy) PIG-1

Above $240^{\circ} \mathrm{C}$ the samples were further AF demagnetized. All diagrams are projected in up/West. Sample $\mathbf{K Z 7 8}$ has a downward directed inclination indicating a normal (N) polarity. Its linear decay is characteristic for high quality group KZ1 (Tab. 1). Sample KZ56 suggests a reversed (R) polarity, but the trend is less linear thus it belongs to intermediate group $\mathbf{K Z 2}$. Sample $\mathbf{K Z 8 9}$ has a very shallow inclination of $c .2 .3^{\circ}$, which is not likely to occur in the study area, therefore it belongs to low quality group KZ3 (Tab. 1); for other explanations see Figure 5

Reprezentatywne przykłady diagramów termicznego (TH) rozmagnesowania próbek z otworu wiertniczego Kazimierza Wielka (Donosy) PIG-1

Po osiągnięciu temperatury powyżej $240^{\circ} \mathrm{C}$ próbki rozmagnesowywano w zmiennym polu magnetycznym (AF). Wszystkie diagramy są zorientowane na zachód. Próbkę KZ78 cechuje ukierunkowana w dół inklinacja, wskazująca na normalną $(\mathbf{N})$ polarność i linearny przebieg, typowy dla grupy wyników wysokiej jakości (KZ1, tab. 1). Próbkę KZ56 charakteryzuje odwrócona (R) polarność i mniej linearny przebieg krzywej, odpowiadający grupie danych pośredniej jakości (KZ2). Krzywa próbki KZ89 wykazuje niewielką inklinację (ok. 2,3), nietypową dla całości wyników i przypisano ją grupie niskiej jakości danych (KZ3, tab. 1); pozostałe objaśnienia na figurze 5 
ChRM - directions

A Thermal + AF (current study)

B

Robot AF (preliminary study)
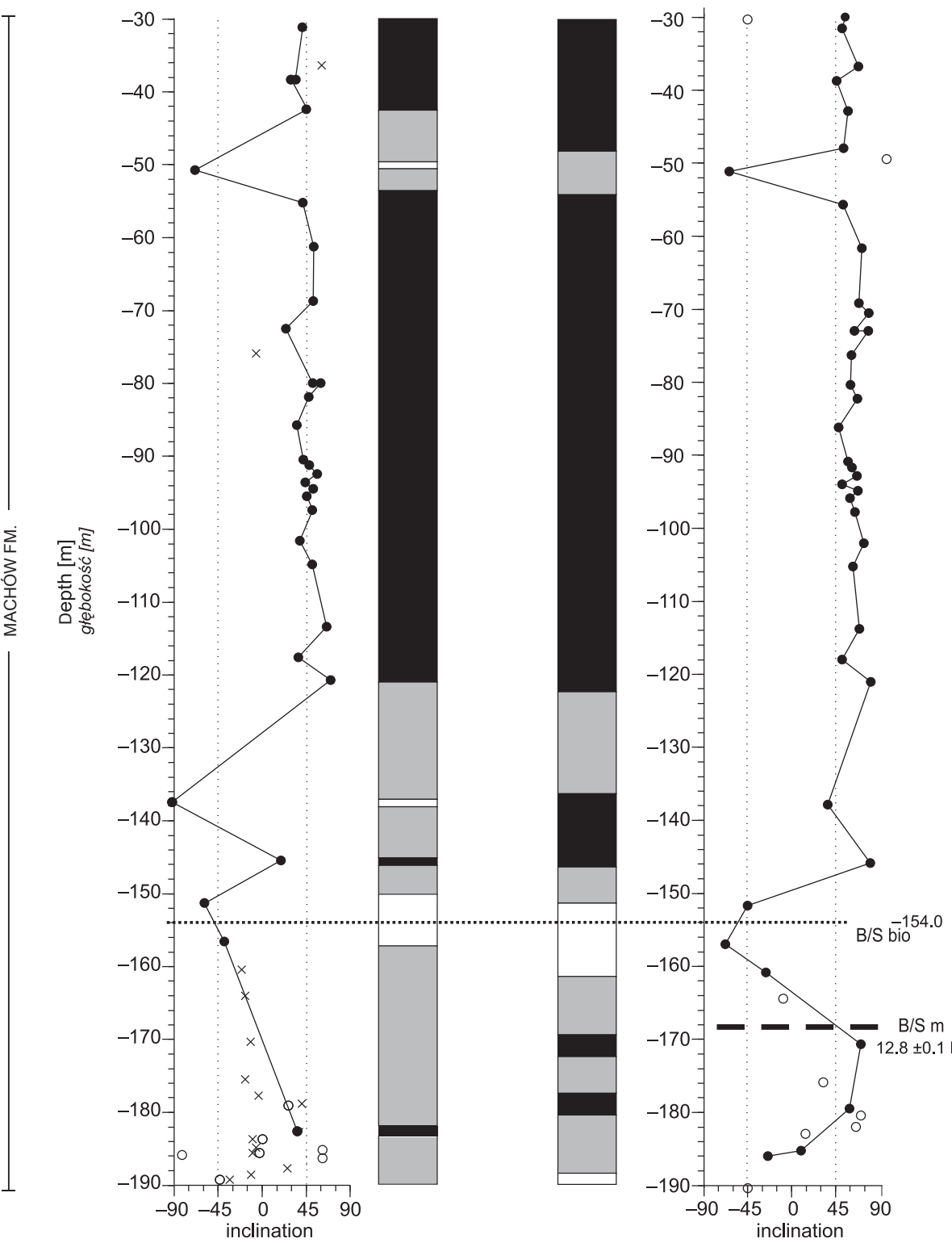

normal polarity intervals

normalna biegunowość

ziemskiego pola magnetycznego

reversed polarity intervals

odwrócona biegunowość

ziemskiego pola magnetycznego

low quality signal samples

niska jakość sygnału magnetycznego

$\mathrm{B} / \mathrm{S}$ bio location interval of the Badenian-Sarmatian boundary based on biostratigraphic data (after forams - Paruch-Kulczycka, 2015)

granica baden-sarmat oparta na danych biostratygraficznych (wg otwornic - Paruch-Kulczycka, 2015)

$\mathrm{B} / \mathrm{S} \mathrm{m}$ suspected location interval of the Badenian-Sarmatian boundary based on paleomagnetic data przypuszczalna granica baden-sarmat oparta na danych paleomagnetycznych

Fig. 7. Polarity column and inclination plot for paleomagnetic results of thermal demagnetization (A) and alternating field demagnetization (B) of the Kazimierza Wielka (Donosy) PIG-1 borehole

The results allow only a tentative correlation to the Geomagnetic Polarity Time Scale

Kolumna polarności ziemskiego pola magnetycznego i wartości inklinacji magnetycznej, na podstawie wyników termicznego rozmagnesowania (A) oraz wyników rozmagnesowania zmiennym polem magnetycznym (B) dla próbek z rdzenia wiertniczego Kazimierza Wielka (Donosy) PIG-1 


\section{DISCUSSION}

In both the Kazimierza Wielka (Donosy) PIG-1 and Busko (Młyny) PIG-1 cores, the Badenian intervals have a rather weak and complicated magnetic signal. Based on the polarity pattern alone a straightforward correlation to the GPTS is not possible. The Kazimierza Wielka (Donosy) PIG-1 core, however, extends downwards to the top of the Badenian evaporites. A volcanic ash layer, just above the evaporites in the Carpathian Foredeep of Romania has recently been dated by the Ar/Ar method at an age of 13.36 Ma (de Leeuw et al., 2013). Accepting this age as an additional age constraint, the lowermost reversed polarity interval most likely corresponds to C5AAr. The normal polarity interval between $-185 \mathrm{~m}$ and $-170 \mathrm{~m}$ could then correspond to C5AAn, the reversed interval between $-170 \mathrm{~m}$ and $-150 \mathrm{~m}$ to C5Ar.3r (Fig. 7). The Badenian-Sarmatian transition roughly corresponds to a transition from reversed to normal polarity, and should then correlate to either C5A2.2n or C5Ar.1n. The age of the Badenian-Sarmatian transition in this correlation arrives at an age of $12.8 \pm 0.1 \mathrm{Ma}$. This correlation is in good agreement with the recently proposed age of c. 12.7 Ma for the BadenianSarmatian transition in the Vienna Basin (Piller et al., 2007) and the Transylvania Basin (de Leeuw et al., 2013).

Radio-isotopic (Ar/Ar) dating indicates that the Badenian halite deposition in the Carpathian Foredeep of southern Poland continued at least till $13.60 \pm 0.07 \mathrm{Ma}$ (de Leeuw et al., 2010). The age of the tuff occurring c. $3.5 \mathrm{~m}$ above Badenian gypsum unit in the eastern Poland has an age of 13.06 $\pm 0.11 \mathrm{Ma}$ (Śliwiński et al., 2012). This last dating corresponds with the estimated age of $13.19 \pm 0.14$ Ma for the pyroclastic horizon found above the sulphates in the equivalent Kosovian (Late Badenian) marly deposits from Schyrets' in western Ukraine (Nejbert et al., 2012). In the studied core Kazimierza Wielka (Donosy) PIG-1 the reversal in between the chrons C5AAn (normal) and C5Ar.3r (reversed) with an age of $12.8 \pm 0.1$ Ma could be related to the Badenian-Sarmatian boundary.

The two normal polarity chrons straddling the BadenianSarmatian transition are, however, of very short duration $(<100 \mathrm{kyr})$, which is in disagreement with the long normal polarity interval $(-150 \mathrm{~m}$ to $-30 \mathrm{~m})$ encompassing most of the lower Sarmatian. FORC diagrams of the samples from the Sarmatian part of the core indicate that the magnetic signal is carried by diagenetic single domain (SD) greigite throughout this interval, which is probably of secondary origin. This means that the normal polarity directions are an overprint of a younger age, most likely from the very recent Brunhes chron. Consequently, the long normal interval in the Sarmatian part of the cores cannot be used to establish a correlation to the GPTS.

It is remarkable that we observe a significant change in magnetic properties, contemporaneous with the paleoenvironmental changes at the Badenian-Sarmatian boundary. At this level, many marine Badenian species became extinct and were replaced by Sarmatian assemblages that are characteristic of more restricted environments. It has been inferred from paleontological and geochemical analyses that the Paratethys Sea experienced changes in salinity, alkalinity and water-mass stratification. We thus conclude that this Paratethys-wide paleoenvironmental change that occurred at the Badenian-Sarmatian transition had probably also created different conditions for the formation and/or preservation of magnetic minerals.

\section{CONCLUSIONS}

We have performed rock magnetic and magnetostratigraphic analyses on two drill cores of the North Carpathian Foredeep that straddle the Badenian-Sarmatian transition. The results from the Kazimierza Wielka (Donosy) PIG-1 and Busko (Młyny) PIG-1 cores warrant several preliminary conclusions on the palaeoenvironmental changes that took place in the Paratethys Sea during this event. They are as follows:

- thermoremanent analyses, hysteresis properties, together with the observation of gyroremanence acquisition during alternating field demagnetization, indicate that the paleomagnetic signal in the cores from Poland is carried by the iron sulphide greigite;

- the paleomagnetic signal of the Badenian samples is of much lower intensity than that of the Sarmatian samples;

- the observed $\mathrm{R}-\mathrm{N}-\mathrm{R}$ polarity pattern in the Badenian part of the Kazimierza Wielka (Donosy) PIG-1 core suggests a tentative correlation to chrons C5AAr-C5Aan-C5Ar.3r of the GPTS, indicating an age of $12.8 \pm 0.1 \mathrm{Ma}$ for the Badenian-Sarmatian transition;

- FORC diagrams of the Sarmatian samples clearly indi- cate that greigite is of diagenetic and secondary origin, probably related to a sub-recent overprint of the Brunhes chron;

- the Paratethys-wide paleoenvironmental changes that occurred at the Badenian-Sarmatian transition had also created different conditions for the formation and/or preservation of magnetic minerals.

Acknowledgements. We would like to thank Silja Hüsing for her supervision during the laboratory experiments. We are also grateful to Cor Langereis, Mark Dekkers and Maxim Krasnoperov for fruitful discussions, performing the af-demagnetization and interpretation of the first paleomagnetic analyses. Special thanks to Marius Stoica for explaining the various paleontological changes during the Badenian-Sarmatian transition event. Two reviewers: Elżbieta Król and Krzysztof Bukowski, are thanked for their comments on this paper.

This work has been sponsored by the National Fund of Environmental Protection and Water Management of Poland and the statutory financial PGI-NRI (project no 6.94.0005.00.0). 


\section{REFERENCES}

BUTLER R.F, 1992 - Paleomagnetism: Magnetic Domains to Geologic Terranes. Blackwell Scientific Publications, London.

CRIHAN I.M., 2002 - Sarmatian foraminifera assemblages from the Melicesti Syncline (Subcarpathians of Muntenia) and their paleoecological significance. A case study. Geol., Sp. Issue, 1: 153-164.

CRIHAN I.M., MARUNTEANU M., 2006 - The Badenian-Sarmatian transition in the Melicesti Syncline (Subcarpathians of Muntenia, Romania). XVIII Congress of the Carpathian-Balkan Geological Association. Belgrade, Serbia, September 3-6, 2006: 83-86

CZAPOWSKI G., 1984 - Osady barierowe w górnym miocenie południowego obrzeżenia Gór Świętokrzyskich. Prz. Geol., 32, 4: 185-194.

CZAPOWSKI G., GA_SIEWICZ A., 2015 - Wykształcenie, stratygrafia i środowiska depozycji utworów pogranicza badenu i sarmatu z SW otoczenia Gór Świętokrzyskich - profile otworów badawczych Busko (Młyny) PIG-1 i Kazimierza Wielka (Donosy) PIG-1. Biul. Państw. Inst. Geol., 461: 9-52.

CZAPOWSKI G., STUDENCKA B., 1990 - Studium sedymentologiczno-paleontologiczne osadów barierowych dolnego sarmatu w rejonie Chmielnika (południowe obrzeżenie Gór Świętokrzyskich). Prz. Geol., 38, 3: 117-127.

DANKERS P.H.M., ZIJDERVELD J.D.A. 1981 - Alternating field demagnetization of rocks, and the problem of gyromagnetic remanence. Earth Planet. Sci. Lett., 53: 89-92.

FILIPESCU S., SILYE L, 2008 - New Paratethyan biozones of planktonic foraminifera described from the Middle Miocene of the Transylvanian Basin (Romania). Geol. Carpath., 59: 537-544.

GĄSIEWICZ A., 2000 - Sedymentologia i diageneza wapieni poselenitowych a model genetyczny polskich złóż siarki rodzimej. Pr. Państw. Inst. Geol., 172.

GĄSIEWICZ A., CZAPOWSKI G., PARUCH-KULCZYCKA J., 2004 - Granica baden-sarmat w zapisie geochemicznym osadów w północnej części zapadliska przedkarpackiego - implikacje stratygraficzne. Prz. Geol., 52: 413-420.

GEDL P., 1999 - Palaeoenvironmental and sedimentological interpretation of the palynofacial analysis of the Miocene desposits from the Jamnica S-119 borehole (Carpathian Foredeep, Poland). Geol. Quart., 43, 4: 479-492.

HARZHAUSER M., PILLER W.E., 2007 — Benchmark data of a changing sea - Palaeogeography, Palaeobiogeography and events in the Central Paratethys during the Miocene. Palaeogeogr., Palaeoclimatol., Palaeoecol., 253: 8-31.

HARZHAUSER M., PILLER W.E., STEININGER F.F., 2002 Circum-Mediterranean Oligo-Miocene biogeographic evolution - The gastropods' point of view. Palaeogeogr., Palaeoclimatol., Palaeoecol., 183: 103-133.

JASIONOWSKI M., 1997 - Zarys litostratygrafii osadów mioceńskich wschodniej części zapadliska przedkarpackiego. Biul. Państw. Inst. Geol., 375: 43-60.

KIRSCHVINK J.L., 1980 - The least-squares line and plane and the analysis of palaeomagnetic data. Geophys. J. Royal Astronomical Society, 62: 699-718.

KRIJGSMAN W., STOICA M., VASILIEV I., POPOV V.V., 2010 - Rise and fall of the Paratethys Sea during the Messinian salinity crisis. Earth Planet. Sci. Lett., 290: 183-191.
KRÓL E., JELEŃSKA M., 1999 - The local magnetostratigraphic scale for the supra-evaporitic Miocene deposits in the northern part of Carpathian Foredeep and its stratigraphic implications (drill-core Jamnica S-119). Geol. Quart., 43, 4: 509-518.

KRZYWIEC P., 2001 - Contrasting tectonic and sedimentary history of the central and eastern parts of the Polish Carpathian Foredeep basin - results of seismic data interpretation. Marine and Petroleum Geology, 18: 13-38.

de LEEUW A., BUKOWSKI K., KRIJGSMAN W., KUIPER K.F., 2010 - Age of the Badenian salinity crisis; impact of Miocene climate variability on the circum - Mediterranean region. Geology, 38: 715-718.

de LEEUW A., FILIPESCU S., MAȚENCO L., KRIJGSMAN W., KUIPER K., STOICA M., 2013 - Paleomagnetic and chronostratigraphic constraints on the Middle to Late Miocene evolution of the Transylvanian Basin (Romania): Implications for Central Paratethys stratigraphy and emplacement of the Tisza-Dacia plate. Global and Planetary Change, 103: 82-98.

ŁUCZKOWSKA E., 1967 - Remarks on Foraminifers described from the Miocene of Wieliczka by A.E. Reuss in 1867. Bull. Inst. Geol., 5: 328-336.

MATENCO L., BERTOTTI G., 2000 — Tertiary tectonic evolution of the external East Carpathians (Romania). Tectonophysics, 316: $255-286$.

NEJBERT K., ŚLIWIŃSKI M. G., BENOWITZ J., LAYER P., YATSYSHYN A., TOMENIUK O., OLSZEWSKA-NEJBERT D., BABEL M., 2012 - ${ }^{40} \mathrm{Ar} /{ }^{39} \mathrm{Ar}$ dating of late Badenian pyroclastic deposits from Schyrets' (near Lviv, Ukraine) and its stratigraphic significance. In: Environmental, Structural and Stratigraphical Evolution of the Western Carpathians (eds. Š. Jósa et al.). $8^{\text {th }}$ Conference 2012, Abstract Book, 6-7 December, Bratislava: 33.

NEY R., BURZEWSKI W., BACHLEDA T., GÓRECKI W., JAKÓBCZAK K., SŁUPCZYŃSKI K., 1974 — Zarys paleogeografii i rozwoju litologiczno-facjalnego utworów miocenu zapadliska przedkarpackiego. Pr. Geol. PAN, 82: 1-65.

OSZCZYPKO N., OSZCZYPKO-CLOWES M., 2012 - Stages of development in the Polish Carpathian Foredeep Basin. Cent. Eur. J. Geosc., 4: 138-162.

OSZCZYPKO N., ŚLACZKA A. 1989 - The evolution of the Miocene basin in the Polish Outer Carpathians and their foreland. Geol. Zbor. Geol. Carpath., 40: 23-36.

PARUCH-KULCZYCKA J., 1999 - Genus Silicoplacentina (Class Amoebina) from the Miocene Machów Formation (Krakowiec Clays) of the northern Carpathian Foredeep. Geol. Quart., 43, 4: 499-508.

PARUCH-KULCZYCKA J., 2015 - Biostratygrafia osadów miocenu z otworów wiertniczych Busko (Młyny) PIG-1 I Kazimierza Wielka (Donosy) PIG-1 na podstawie otwornic (północna część zapadliska przedkarpackiego) Biul. Państw. Inst. Geol., 461: $115-132$.

PASSIER H.F., DE LANGE G.J., DEKKERS M.J., 2001 - Magnetic properties and geochemistry of the active oxidation front and the youngest sapropel in the eastern Mediterranean Sea. Geophys. J. Int., 145: 604-614.

PAULISSEN W., LUTHI S.M., GRUNERT P., ĆORIĆ S., HARZHAUSER M., 2011 — Integrated high-resolution stratigra- 
phy of a Middle to Late Miocene sedimentary sequence in the central part of the Vienna Basin. Geol. Carpath., 62: 155-169.

PAWŁOWSKI S., PAWŁOWSKA K., KUBICA B., 1979 - Geology and genesis of the Polish sulphur deposits. Economic Geology, 74: 475-483.

PAWŁOWSKI S., PAWŁOWSKA K., KUBICA B., 1985 - Budowa geologiczna tarnobrzeskiego złoża siarki rodzimej. Pr. Inst. Geol., 114: 1-109.

PISERA A., 1996 - Miocene reefs of the Paratethys: a review. Concepts in Sedimentology and Paleontology, 5: 97-104.

PILLER W.E., HARZHAUSER M., MANDIC O., 2007 - Miocene Central Paratethys stratigraphy - current status and future directions. Stratigraphy, 4: 151-168.

POPOV S. V., SHCHERBA I. G., ILYINA L. B., NEVESSKAYA L.A., PARAMONOVA N.P., KHONDKARIAN S.O., MAGYAR I., 2006 - Late Miocene to Pliocene palaeogeography of the Paratethys and its relation to the Mediterranean. Palaeogeogr., Palaeoclimatol., Palaeoecol., 238: 91-106.

RAMSTEIN G., FLUTEAU F., BESSE J., JOUSSAUME S., 1997 Effect of orogeny, plate motion and land-sea distribution on Eurasian climate change over the past 30 million years. Nature, 386: 788-795.

ROBERTS A.P., 1995 - Magnetic properties of sedimentary greigite $\left(\mathrm{Fe}_{3} \mathrm{~S}_{4}\right)$. Earth Planet. Sci. Lett., 134: 227-236.

ROBERTS A.P., CHANG L., ROWAN C.J., HORNG C-S., FLORINDO F., 2011 - Magnetic properties of sedimentary greigite $\left(\mathrm{Fe}_{3} \mathrm{~S}_{4}\right)$ : An update. Rev. Geoph., 49. RG1002, doi: 10.1029/2010RG000336.

ROBERTS A. P., LIU Q., ROWAN C. J., CHANG L., CARVALLO C., TORRENT J., HORNG C. S., 2006 - Characterization of hematite $\left(\alpha-\mathrm{Fe}_{2} \mathrm{O}_{3}\right)$, goethite $(\alpha-\mathrm{FeOOH})$, greigite $\left(\mathrm{Fe}_{3} \mathrm{~S}_{4}\right)$, and pyrrhotite $\left(\mathrm{Fe}_{7} \mathrm{~S}_{8}\right)$ using first-order reversal curve diagrams. J. Geoph. Res., 111. B12S35, doi:10.1029/2006JB004715.

RÖGL F., 1999 - Mediterranean and Paratethys. Facts and hypotheses of an Oligocene to Miocene Paleogeography (short overview). Geol. Carpath., 50: 339-349.

SADOWSKA A., 1999 - Sarmatian palynoflora from Jamnica near Tarnobrzeg (Carpathian Foredeep) - environmental and climatic implications. Geol. Quart., 43, 4: 493-498.

SNOWBALL, I. F., 1997 - Gyroremanent magnetization and the magnetic properties of greigite bearing clays in southern Sweden. Geophys. J. Int., 129: 624-636.
STUDENCKA B., JASIONOWSKI M., 2011 - Bivalves from the Middle Miocene reefs of Poland and Ukraine: A new approach to Badenian/Sarmatian boundary in the Paratethys. Acta Geol. Pol., 61: 79-114.

ŚLIWIŃSKI M., BĄBEL M., NEJBERT K., OLSZEWSKANEJBERT D., GĄSIEWICZ A., SCHREIBER B.C., BENOWITZ J.A., LAYER P., 2012 - Badenian-Sarmatian chronostratigraphy in the Polish Carpathian Foredeep. Palaeogeogr., Palaeoclimatol., Palaeoecol., 326-328: 12-29.

TER BORGH M., VASILIEV I., STOICA M., KNEŽEVIĆ S., MATENCO L., KRIJGSMAN W., RUNDIĆ L., CLOETINGH S., 2013 - The isolation of the Pannonian basin (Central Paratethys): new constraints from magnetostratigraphy and biostratigraphy. Global and Planetary Change, 103: 99-118.

VASILIEV I., MAȚENCO L., KRIJGSMAN W., 2009 — The syn- and post-collisional evolution of the Romanian Carpathian Foredeep: New constraints from anisotropy of magnetic susceptibility and paleostress analyses. Tectonophysics, 473: 457-465.

VASILIEV I., DEKKERS M.J., KRIJGSMAN W., FRANKE C., LANGEREIS C.G., MULLENDER T.A.T., 2007 — Early diagenetic greigite as a recorder of the palaeomagnetic signal in Miocene-Pliocene sedimentary rocks of the Carpathian Foredeep (Romania). Geophys. J. Int., 171: 613-629.

VASILIEV I., FRANKE C., MEELDIJK J.D., DEKKERS M.J., LANGEREIS C.G., KRIJGSMAN W., 2008 - Putative greigite magnetofossils from the Pliocene epoch. Nature Geoscience, 11: 782-786.

VASILIEV I., KRIJGSMAN W., LANGEREIS C.G., PANATOIU C.E., MAȚENCO L., BERTOTTI G., 2004 - Towards an astrochronological framework for the eastern Paratethys MioPliocene sedimentary sequences of the Focşani basin (Romania). Earth Planet. Sci. Lett., 227: 231-247.

VASILIEV I., de LEEUW A., FILIPESCU S., KRIJGSMAN W., KUIPER K., STOICA M., BRICEAG A., 2010 - The age of the Sarmatian-Pannonian transition in the Transylvanian Basin (Central Paratethys). Palaeogeogr., Palaeoclimatol., Palaeoecol., 297: 54-69.

ZIJDERVELD J.D.A., 1967 - A.C. demagnetization of rocks: analysis of results. In: Developments in solid Earth Geosciences Methods in palaeomagnetism (eds. D.W. Collison et al.): 254-286. Elsevier Publishing Company, Amsterdam.

\section{STRESZCZENIE}

Przebadane próbki utworów z pogranicza badenu i sarmatu (fig. 1), pobrane z dwóch otworów wiertniczych - Busko (Młyny) PIG-1 i Kazimierza Wielka (Donosy) PIG-1, odwierconych w północnej części zapadliska przedkarpackiego na terenie Polski (fig. 2B), wykazują właściwości GRM (gyroremanent magnetization - podatność magnetyczna), często o wielkości magnetyzacji wyżzzej niż NRM (natural remanent magnetizations - naturalna podatność magnetyczna), niekiedy nawet o rząd wielkości. Cecha ta jest typowa dla minerału greigitu i można z całą pewnością stwierdzić, że ten siarczek żelaza jest głównym nośnikiem namagnesowania w utworach formacji z Machowa. Wyniki badań próbek z profilu Kazimierza Wielka (Donosy) PIG-1 są bardziej jednoznaczne dzięki wysokiej wartości GRM (fig. 3). Intensywny sygnał i wyraźne magnetyczne kierunki są typowe dla większości próbek z tego otworu (fig. 4). Rozkład polarności tego profilu cechuje wysoka jakość, wyniki badań większości próbek można zinterpretować. Proste linie, wybiegające z poszczególnych punktów z danymi (zawierającymi też informacje o genezie utworów), ukazują wektor zinterpretowanego kierunku paleomagnetycznego (fig. 5, 6; tab. 1). Podczas polowej demagnetyzacji siarczki żelaza wy- 
kazały efekt żyroskopowy, prowadzący do znacznego wzrostu intensywności magnetycznej i zaburzenia diagramów demagnetyzacyjnych o ponad $45 \mathrm{mT}$. Stwierdzone kierunki są oparte na przedziałach wektorów pomiędzy wartościami natężenia pola rozmagnensowującego $20 \mathrm{mT}$ a $40 \mathrm{mT}$.

Ogólny obraz magnetostratygraficzny dla profilu Kazimierza Wielka (Donosy) PIG-1 w dolnej części jest zdominowany przez odwróconą polarność (głęb. 150-200 m), natomiast w górnej części występuje normalna polarność (głęb. 30-150 m). Na głębokości 170 m w tym profilu (fig. 7) następuje przejście polarności odwróconej do normalnej. Przejście to można wstępnie korelować z sukcesją chron C5AAr-C5AAn-C5Ar.3r globalnej skali paleomagnetycznej (GPTS) i jest datowane na 12,8 $\pm 0,1 \mathrm{Ma}$. Najnowsze oznaczenia wieku bezwzględnego w profilu badeńsko-sarmackich utworów dotyczą określenia metodą Ar/Ar wieku stropu badeńskich ewaporatów. W Rumunii wykazały one wiek rzędu 13,36 Ma (de Leeuw i in., 2013), natomiast poziom tufitowy znajdujący się ponad badeńską serią gipsową we wschodniej części zapadliska przedkarpackiego - 13,06 $\pm 0,11 \mathrm{Ma}$ (Śliwiński i in., 2012).
Oprócz właściwości GRM, skały zawierające greigit wykazują inne problemy ze zmiennym polem demagnetyzacji. W pewnych przypadkach stosowana technika nie pozwala na wystarczające rozdzielenie pierwotnych i wtórnych (nałożonych) sygnałów (wyników). Lepszą, lecz bardziej czasochłonną techniką demagnetyzacji tych skał jest demagnezacja termiczna. We wcześniejszych pracach (Vasiliev i in., 2007, 2008, 2010; Krijgsman i in., 2010) wykazano, że demagnetyzacja termiczna daje bardziej wiarygodne informacje magnetostratigraficzne utworów z obszaru Paratetydy i należy ją zastosować do wszystkich zbadanych próbek.

W przypadku próbek pobranych z profilu otworu wiertniczego Busko (Młyny) PIG-1 wyniki badań podatności magnetycznej były dość jednorodne, nie zanotowano wyraźnych zmian w polarności, co nie pozwoliło na ich wystarczająco wiarygodną interpretację. Zmiany środowiskowe na obszarze Paratetydy na pograniczu badenu i sarmatu wpłynęły w różny sposób na powstanie i przemiany minerałów o właściwościach magnetycznych. 